\title{
Gastric Papillary Adenocarcinoma
}

National Cancer Institute

\section{Source}

National Cancer Institute. Gastric Papillary Adenocarcinoma. NCI Thesaurus. Code C5472.

A variant of gastric adenocarcinoma with exophytic growth and elong ated finger-like processes lined by cylindrical or cuboidal cells supported by fibrovascular connective tissue cores. 